\title{
PENGARUH SISTEM INFORMASI AKUNTANSI PENJUALAN DAN PENGENDALIAN INTERNAL TERHADAP EFEKTIVITAS PENGENDALIAN PIUTANG PADA PT BAROKAH ADI SEJAHTERA MEDAN
}

\author{
${ }^{1}$ Hari Cahyo" ${ }^{2}$ Henny Tri Astuti KN ${ }^{3}$ Farida Khairani Lubis \\ ${ }^{1,2,3}$ Universitas Islam Sumatera Utara \\ ${ }^{1}$ Heri.cahyo@gmail.com, ${ }^{2}$ henny.triastuty@fe.uisu.ac.id, ${ }^{3}$ farida.khariani@fe.uisu.ac.id
}

\begin{abstract}
PT. Barokah Adi Sejahtera Medan is a company engaged in cargo and shipping services. In carrying out its business, the sales accounting information system and internal control must be implemented properly so that receivables can be minimized effectively. The operational activities and transactions that occur daily look diverse. In an effort to increase sales of the company, the need to control receivables that have an important role to sell in order for the sales to occur in accordance with procedures and able to generate maximum profitability for the company. The research concluded that accounting information systems have a positive and significant effect on receivables control as the results of the study based on the t test that $t$-count is greater than the $t$ table of $2.94>2.02$. Internal Control has a positive and significant effect on receivable control as the results of the study based on the t-test that the t-count is greater than the t-table of 2.92> 2.02. Simultaneously or jointly Accounting Information System (X1) and Internal Control (X2) affect receivable control $(Y)$ as the calculation of simultaneous tests i.e. F-count is greater than f-table or $8,285>4.08$. The magnitude of the influence of variable X1, X2 on[ variable Y based on determinant test is $55.60 \%$
\end{abstract}

Keywords : Accounting Information System, Internal Control and Receivable Control

ABSTRAK : PT. Barokah Adi Sejahtera Medan adalah sebuah perusahaan yang bergerak di bidang jasa Cargo dan pengiriman. Dalam menjalankan usahanya sistem informasi akuntansi penjualan dan pengendalian internal harus diterapkan dengan baik sehingga piutang dapat diminimalisir secara efektif. Adapun aktivitas operasional dan transaksi yang terjadi sehari-hari terlihat beragam. Dalam upaya meningkatnya penjualan perusahaan diperlukannya pengendalian piutang yang memiliki peran penting terhadap penjualan agar penjualan yang terjadi sesuai dengan prosedur dan mampu menghasilkan profitabilitas yang maksimum bagi perusahaan. Penelitian memberikan kesimpulan bahwa sistem informasi akuntansi berpengaruh positif serta signifikan terhadap pengendalian piutang sebagaimana hasil penelitian berdasarkan uji t bahwa thitung lebih besar dari t-tabel yaitu 2,94 > 2.02. Pengendalian Internal berpengaruh positif dan signifikan terhadap pengendalian piutang sebagaimana hasil penelitian berdasarkan uji t bahwa thitung lebih besar dari t-tabel yaitu 2,92> 2.02. Secara simultan atau bersama Sistem Informasi Akuntansi $\left(X_{1}\right)$ dan Pengendalian Internal $\left(X_{2}\right)$ berpengaruh terhadap Pengendalian Piutang $(Y)$ sebagaimana perhitungan uji simultan yaitu F-hitung lebih besar dari f-tabel atau 8,285 > 4,08. Adapun besaran pengaruh dari variable $X_{1}, X_{2}$ terhadap[ variable $Y$ berdasarkan uji determinan adalah $55,60 \%$

Kata Kunci : Sistem Informasi Akuntansi, Pengendalian Internal dan Pengendalian Piutang

\section{Pendahuluan}

\subsection{Latar Belakang Masalah}

PT. Barokah Adi Sejahtera Medan adalah perusahaan yang bergerak di bidang jasa Cargo dan pengiriman. Perusahaan dalam menjalankan usahanya sistem informasi akuntansi penjualan dan pengendalian internal harus diterapkan dengan baik sehingga piutang dapat dikendalikan secara efektif dan efisien. Aktivitas operasional dan transaksi yang terjadi sehari-hari terlihat beragam. Terjadinya peningkatan penjualan perusahaan diperlukannya pengendalian piutang yang memiliki peran penting terhadap penjualan agar penjualan yang terjadi sesuai dengan prosedur 
dan mampu menghasilkan profitabilitas yang maksimum bagi perusahaan.

Adapun bentuk transaksi yang dilakukan oleh perusahaan PT. Barokah Adi Sejahtera adalah dilakukan dengan proses dimana diawali dengan pesanan costumer mobil dan kasih packing list di email, kemudian pihak vendor menganalisa atas unit/armada yang dipakai, selanjutnya vendor threshing dari awal berangkat sampai ke tujuan agar aman dan dan sampai tepat waktu, selanjutnya vendor meminta STT embali dari driver dan memastikan surat-surat yang kembali sudah benar, vendor membuat invoice yang dilengkapi dengan faktur pajak dan invoice dikirim ke customer dengan TOP kontrak yang ditentukan untuk difollow upa oleh vendor kemudian invoice yang sudah menerima menyetor pajak dengan bukti penerimaan pajak yang dikirim ke pihak cutomer melalui email PDF.

Berdasarkan latar belakang tersebut menjadi dasar pemikiran bagi penulis untuk mengetahui sejauhmana sistim manajemen akuntansi dan pengendalian internal dalam mengefektifkan pengendalian piutang perusahaan, hal inilah yang menjadi alasan bagi penulis sehingga menetapkan judul : Pengaruh Sistem Informasi Akuntansi Penjualan Dan Pengendalian Internal Terhadap Efektivitas Pengendalian Piutang Pada PT Barokah Adi Sejahtera Medan.

\subsection{Rumusan Masalah}

Adapun yang menjadi rumusan masalah dalam penelitian ini adalah berkaitan denan pengaruh sistem informasi akuntansi penjualan terhadap efektivitas pengendalian piutang di PT. Barokah Adi Sejahtera Medan. Apakah ada pengaruh pengendalian internal terhadap efektivitas pengendalian piutang di PT. Barokah Adi Sejahtera Medan dan pengaruh sistem informasi akuntansi penjualan dan pengendalian internal terhadap efektivitas pengendalian piutang di PT. Barokah Adi Sejahtera Medan.

\section{Uraian Teoritis}

\subsection{Sistem Informasi Akuntansi Penjualan}

Selanjutnya diketahui bahwa sistem informasi akuntansi penjualan merupakan alat yang memberikaninformasi dan data yang akurat yang harus diterapkan oleh perusahaan perdagangandan juga sistem informasi akuntansi penjualan merupakan aspek khusus yangmenyangkut aktivitas penjualan secara structural organisasioinal, yang dibutuhkanoleh pihak manajemen dalam mengambil keputusan terutama dibidang penjualanmelalui laporan penjualan, dan aktivitas penjualan secara tunai maupun kreditmenjadi sumber pendapatan perusahaan, yang berpengaruh pada pertumbuhanperusahaan.

Dalam upaya keberhasilan aktivitas penjualan menjadi penentu keberhasilan aktivitaspenjualan menjadi penentu keberhasilan pimpinan perusahaan dalam mengelolaperusahaan, sehingga apabila aktivitas penjualan tidak didukung oleh pengelolaanyang baik melalui sistem informasi akuntansu penjuala yang memadai, maka akansangat sulit bagi perusahaan untuk mempertahankan kegiatan perusahan dalam erasekarang ini.

Selanjutnya yang menjadi indikator system informasi akuntansi penjualan menurut Mulyadi (2018:89) adalah:

1. Sumber Daya Manusia dan Alat

2. Catatan

3. Informasi atau laporan-laporan

Berdasarkan uraian di atas diketahui ada beberapa indiator system informasi akuntansi penjualan.

\subsection{Konsep Penjualan}

Penjualan, merupakan salah satu fungsi utama yang cukup penting dalam suatu perusahaan. Tujuan utama perusahaan adalah untuk memperoleh laba dari hasil penjualan yangmerupakan unsur terpenting dalam mempertahankan kelangsungan hidup perusahaan.Penjualan adalah Suatu kegiatan yang terdiri dari tandaksi penjualan barangatau jasa, secara kredit maupun tunai."(Mulyadi, 2018;160).

\subsection{Pengendalian Internal}

Sebagaimana dikatakan Mulyadi (2008) Sistem pengendalian intern meliputi struktur organisasi, metode dan ukuran-ukuran yang dikoordinasikan untuk menjagakekayaan organisasi, mengecek ketelitian dam keandalan data akuntansi, mendorong efisiensi dan mendorong dipatuhinya kebijakan manajamen. Tujuan sistim pengendalian intern menurut definisi tersebut adalah :

a. Menjaga kekayaan organisasi

b. Mengecek ketelitian dan keandalan data akuntansi

c. Mendorong efisiensi

d. Mendorong dipatuhinya kebijakan manajamen 
Adapun indicator pengenalian internal menurut Sanyoto (2021.:146) bahwa indicator pengendalian internal adalah sebagai berikut :

a. Lingkungan Pengendalian

b. Penilaian Resiko

c. Prosedur Pengendalian

d. Informasi dan komunikasi

e. Pemantauan

\subsection{Efektivitas Pengendalian Piutang}

Secara teori bahwa efektivitas adalah pemanfaatan sumber daya, dana, sarana, dan prasarana dalam jumlah tertentu yang secara sadar ditetapkan sebelumnya untuk menghasilkan sejumlah barang dan jasa dengan mutu tertentu tepat pada waktunya Wiratna (2015:70). Dengan demikian Efektivitas dapat diartikan suatu keadaan yang menunjukkan seberapa jauh suatu target yang telah dicapai oleh manajemen seperti kualitas, kuantitas, dan waktu, dimana target tersebut sudah ditentukan terlebih dahulu (Sondang, 2014:20). Efektivitas juga merupakan suatu bentuk perbandingan antara pemanfaatan kemampuan saran perusahaan dengan waktu yang tercapai dalam usahanya untuk mendapatkan hasil yang telah ditetapkan sebelumnya.

Selanjutnya indicator efektivitas pengendalian piiutang adalah sebagai berikut :

a. Pengendalian Pemrosesan informasi

b. Pemisahan tugas yang memadai

c. Pengendalian fisik atas kekayaan dan catatan

d. Review Kinerja

\section{PEMBAHASAN HASIL PENELITIAN}

\subsection{Deskripsi Hasil Penelitian}

Berdasarkan hasil penelitian yang dilakukan oleh peneliti di PT. Barokah Fajar Sejahtera. Peneliti hanya bisa melakukan penelitian mengenai pengaruh Sistem Informasi Akuntansi, Pengendalian Internal terhadap produktivitas kinerja karyawan.

1) Uji Validitas dan Reliabilitas.

a. Uji Validitas.

Dalam uji valaiditas dikatakan valid jika koefisien korelasinya $\left(r_{\text {hitung }}>r_{\text {tabel }}\right)$ dengan $n=$ 40 yakni lebih besar dari 0,312 atau dapat diketahui dengan membandingkan indeks korelasi product moment pearson dengan level signifikansi $95 \%$ sebagai nilai kritisnya. Bila probabilitas hasil korelasi lebih kecil dari 0,05 maka data dinyatakan valid dan sebaliknya. Angket penelitian ini dikatakan Valid dan tidak Valid apabila :

- Jika $r_{\text {hitung }}>r_{\text {tabel }} 0,312$ maka dikatakan Valid
- Jika $r_{\text {hitung }}<r_{\text {tabel }} 0,312$ maka dikatakan Tidak Valid

Tabel 1. Validitas Sistem Informasi Akuntansi

\begin{tabular}{|c|c|c|c|}
\multicolumn{5}{|c}{$\mathrm{X}_{1}$} \\
\hline No. & $\mathrm{r}_{\text {hitung }}$ & $\mathrm{r}_{\text {tabel }}$ & Status \\
\hline 1 & 0,542 & 0,312 & Valid \\
\hline 2 & 0,620 & 0,312 & Valid \\
\hline 3 & 0,588 & 0,312 & Valid \\
\hline 4 & 0,588 & 0,312 & Valid \\
\hline 5 & 0,555 & 0,312 & Valid \\
\hline 6 & 0,700 & 0,312 & Valid \\
\hline 7 & 0,668 & 0,312 & Valid \\
\hline 8 & 0,568 & 0,312 & Valid \\
\hline
\end{tabular}

Sumber : Hasil Penelitian (data diolah) 2021.

Penelitian validitas variabel Sistem Informasi Akuntansi kusenioner dengan jumlah anggota sampel sebanyak 40 orang menggunakan program SPSS, butir pernyataan dalam kuesionerl disebut valid bila $t_{\text {hitung }}$ (seperti yang tertera pada kolom Corrected Total Item Corelations sebagai output SPSS untuk $\mathrm{n}$ sebanyak 40 adalah 0,312 sehingga $\mathrm{r}_{\text {hitung }}$ tiap butir pernyataan yang tersisa dalam kuesioner telah valid (seperti yang tertera pada lampiran) dan selanjutnya dapat digunakan dalam penelitian.

Tabel 2. Uji Validitas Pengendalian Internal $\mathrm{X}_{2}$

\begin{tabular}{|c|c|c|c|}
\hline No. & $\mathrm{r}_{\text {hitung }}$ & $\mathrm{r}_{\text {tabel }}$ & Status \\
\hline 1 & 0,588 & 0,312 & Valid \\
\hline 2 & 0,555 & 0,312 & Valid \\
\hline 3 & 0,700 & 0,312 & Valid \\
\hline 4 & 0,416 & 0,312 & valid \\
\hline 5 & 0,668 & 0,312 & Valid \\
\hline 6 & 0,436 & 0,312 & Valid \\
\hline 7 & 0,542 & 0,312 & Valid \\
\hline 8 & 0,620 & 0,312 & Valid \\
\hline \multicolumn{4}{|c|}{ Sumber : Hasil Penelitian } \\
\hline
\end{tabular}
(data diolah) 2021

Penelitian validitas variabel Pengendalian Internal dengan kusenioner jumlah anggota sampel sebanyak 40 orang menggunakan program SPSS, butir pernyataan dalam kuesionerl disebut valid bila $t_{\text {hitung }}$ (seperti yang tertera pada kolom Corrected Total Item Corelations sebagai output SPSS untuk-n sebanyak 40 adalah 0,312 sehingga $r_{\text {hitung }}$ tiap butir pernyataan yang tersisa dalam kuesioner telah valid (seperti yang tertera pada lampiran) dan selanjutnya dapat digunakan dalam penelitian. 
Tabel 3. Uji Validitas Variabel Pengendalian Piutang Y

\begin{tabular}{|c|c|c|c|}
\hline No. & $\mathrm{r}_{\text {hitung }}$ & $\mathrm{r}_{\text {tabel }}$ & Status \\
\hline 1 & 0,765 & 0,312 & Valid \\
\hline 2 & 0,551 & 0,312 & Valid \\
\hline 3 & 0,619 & 0,312 & Valid \\
\hline 4 & 0,538 & 0,312 & Valid \\
\hline 5 & 0,565 & 0,312 & Valid \\
\hline 6 & 0,592 & 0,312 & Valid \\
\hline 7 & 0,537 & 0,312 & Valid \\
\hline 8 & 0,570 & 0,312 & Valid \\
\hline \multicolumn{4}{|c}{ Sumber : Hasil Penelitian } \\
(data diolah) 2021.
\end{tabular}

Penelitian validitas variabel Pengendalian Piutang dengan kusenioner jumlah anggota sampel sebanyak 40 orang menggunakan program SPSS, butir pernyataan dalam kuesionerl disebut valid bila $t_{\text {hitung }}$ (seperti yang tertera pada kolom Corrected Total Item Corelations sebagai output SPSS $>\mathrm{t}_{\text {tabel }}$ untuk $\mathrm{n}$ sebanyak 40 adalah 0,312 sehingga $r_{\text {hitung }}$ tiap butir pernyataan yang tersisa dalam kuesioner telah valid (seperti yang tertera pada lampiran) dan selanjutnya dapat digunakan dalam penelitian.

b. Uji Reliabilitas.

Item yang dinyatakan valid dalam uji validitas ditentukan reliabilitasnya dengan kriteria sebagai berikut :

Tabel 4. Uji Reliabilitas

\begin{tabular}{|l|c|c|}
\hline \multicolumn{1}{|c|}{ Variabel } & Croncbac's Alpha & Status \\
\hline Sistem Informasi Akuntansi $\mathrm{X}_{1}$ & 0,801 & Reliabel \\
\hline Pengendalian Internal $\left(\mathrm{X}_{2}\right)$ & 0,785 & Reliabel \\
\hline Pengendalian Piutang Y & 0,739 & Reliabel \\
\hline
\end{tabular}

Sumber : Hasil Penelitian (data diolah) 2021

Dari tabel di atas diketahui bahwa ketiga instrumen penelitian pada penilitian ini telah memenuhi dasar unsur reliabilitas yang terpercaya. Dari tabel di atas dapat diketahui bahwa nilai Alpha Variabel Sistem Informasi Akuntansi sebesar 0,801> $r_{\text {tabel }}$, dan nilai alpha Pengendalian Internal sebesar $0,785>\mathrm{r}_{\text {tabel. }}$. Nilai Alpha variabel Pengendalian Piutang $0,739>r_{\text {tabel. }}$ Maka dapat disimpulkan bahwa instrumen penelitian ini adalah reliabel atau terpercaya atau diandalkan.

\subsection{Uji Asumsi Klasik.}

1) Uji Normalitas.

Adapun uji normalitas data Kolmogorov-Smirnov ada pada tabel berikut:

Tabel 5.Hasil uji Normalitas Data Kolmogorov-Smirnov

\begin{tabular}{|c|c|c|c|c|}
\hline & & $\begin{array}{c}\text { Sistem Informasi } \\
\text { Akuntansi }\end{array}$ & $\begin{array}{l}\text { Pengendalian } \\
\text { Internal }\end{array}$ & $\begin{array}{l}\text { Pengendalian } \\
\text { Piutang }\end{array}$ \\
\hline \multicolumn{2}{|l|}{$\mathrm{N}$} & 40 & 40 & 40 \\
\hline \multirow[t]{2}{*}{ Normal Parameters $^{\mathrm{a}}$} & Mean & 756777423 & 1592739658 & 829106541 \\
\hline & \begin{tabular}{|l} 
Std. \\
Deviation
\end{tabular} & 124781834 & 180299361 & 573779612 \\
\hline \multirow[t]{3}{*}{ Most Extreme Differences } & Absolute & .112 & .107 & .127 \\
\hline & Positive & .058 & .071 & .127 \\
\hline & Negative & -.112 & -.107 & -.084 \\
\hline \multicolumn{2}{|l|}{ Kolmogorov-Smirnov Z } & .550 & .523 & .620 \\
\hline \multicolumn{2}{|l|}{ Asymp. Sig. (2-tailed) } & .923 & .947 & .836 \\
\hline
\end{tabular}

1) Test distribution is Normal.

Sumber : Hasil Penelitian (data diolah) 2021 
Adapun grafik uji Normalitas dapat dilihat pada gambar Berikut :

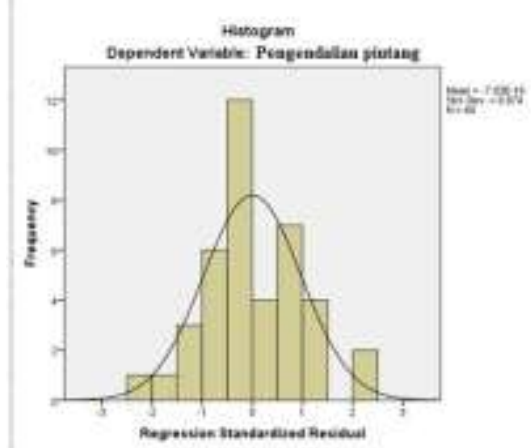

Gambar 1. Grafik Pengujian Normalitas Data

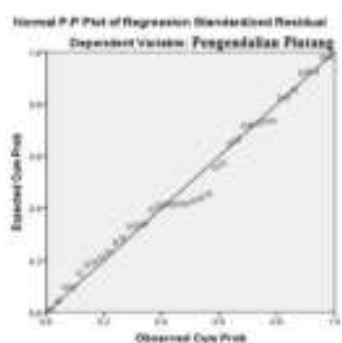

Gambar 2. Normal P.P Plot

2) Pengujian Multikolinearitas.

Sebagaimana hasil uji korelasi tentang variabel indevenden, dapat dilihat bahwa korelasi diantara variabel tersebut relatif tidak tinggi. Tidak ada korelasi yang melebihi 0,60 , hal ini menunjukkan bahwa tidak terjadi masalah multikolinearitas diantara variabel indevenden. Hasil korelasi dapat dilihat pada tabel :

Tabel 6. Hasil Uji Multikolinieritas

Coefficient Correlations $^{\mathrm{a}}$

\begin{tabular}{|l|l|l|r|r|}
\hline \multicolumn{2}{|l|}{ Model } & \multicolumn{1}{|c|}{$\begin{array}{c}\text { Sistem } \\
\text { Inforamsi } \\
\text { Akuntansu }\end{array}$} & $\begin{array}{c}\text { IPengendalianI } \\
\text { nternal }\end{array}$ \\
\hline 1 & Correlations & $\begin{array}{l}\text { Sistem Informasi } \\
\text { Akuntansi }\end{array}$ & 1.000 & -.133 \\
\cline { 3 - 4 } & $\begin{array}{l}\text { Pengendalian } \\
\text { Internal }\end{array}$ & -.133 & 1.000 \\
\cline { 2 - 5 } & Covariances & $\begin{array}{l}\text { Sistem Informasi } \\
\text { Akuntansi }\end{array}$ & .404 & -.078 \\
\cline { 3 - 5 } & $\begin{array}{l}\text { Pengendalian } \\
\text { Internal }\end{array}$ & -.078 & .844 \\
\hline
\end{tabular}

a. Dependent Variable: Pengendalian Piutang Sumber : Hasil Penelitian (data diolah) 2021

Multikolinieritas dapat juga diketahui melalui Variance Inflation Factor (VIF), apabila VIF melebihi angka 10 maka terdapat indikasi multikolinieritas. Angka VIF dalam penelitian ini terdapat pada tabel berikut :

Tabel 7. Hasil Uji Multikolinieritas (VIF)

\begin{tabular}{|c|c|}
\hline \multicolumn{2}{|l|}{ Collinearity Statistics } \\
\hline Tolerance & VIF \\
\hline kuntansi 982 & 1.018 \\
\hline Pengendalian Internal 982 & 1.018 \\
\hline
\end{tabular}

Dari tabel di atas dapat diketahui bahwa VIF masing-masing variabel < 10 maka dapat disimpulkan bahwa tidak ada multikolinieritas.

3) Pengujian Heteroskedastisitas.
Melalui Pengujian heteroskedastisitas diketahui bahwa model regresi tidak terjadi heteroskedastisiitas. Dengan kata lain terjadi kesamaan varian residual dari satu pengamtan kepengamatan lain. Hasil pengujian heteroskedasitas dapat dilihat pada gambar berikut :

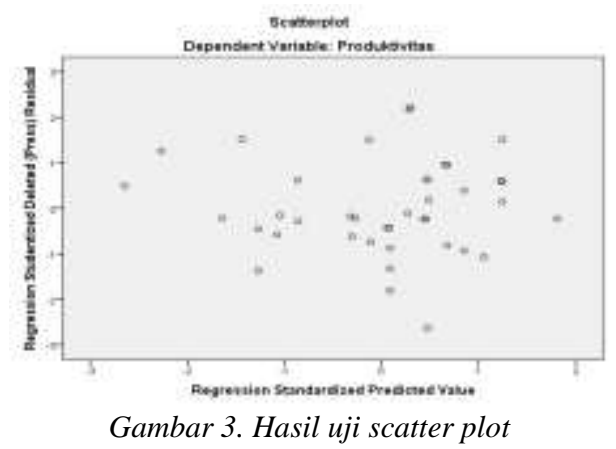


4. Analisis Regresi Linear Berganda.

\subsection{Uji t.}

Penelitian menggunakan regresi linier berganda untuk mengetahui hubungan sistem informasi akuntansi dan pengendalian internal terhadap pengendalian piutang maka dilakukan analisis regresi linier berganda.

Tabel 8. Descriptive Statistics

\begin{tabular}{|l|r|r|r|}
\hline & Mean & Std. Deviation & \multicolumn{1}{|c|}{ N } \\
\hline Pengendalian Piutang & 42.1250 & 3.61753 & 40 \\
Sistem Informasi & 38.2000 & 1.93748 & 40 \\
Akuntansi & 38.7250 & 2.92634 & 40 \\
\hline \multicolumn{2}{|l}{ Pengendalian Internal } & Sumber: Hasil Penelitian (data diolah) 2021.
\end{tabular}

Sesuai dengan program SPSS yang penulis buat diperoleh coefisiensts. Dalam coefisiensts ini dapat dilihat persamaan regresi linear berganda dan Sistem Informasi Akuntansi dan
Pengendalian Internal terhadap Pengendalian Piutang . Tabel coefisiensts yang penulis maksud dapat dilihat pada tabel dibawah ini :

Tabel 9.

Coefficients (a)

\begin{tabular}{|c|c|c|c|c|c|}
\hline \multirow[t]{2}{*}{ Model } & \multicolumn{2}{|c|}{$\begin{array}{l}\text { Unstandardized } \\
\text { Coefficients }\end{array}$} & \multirow{2}{*}{$\begin{array}{c}\begin{array}{c}\text { Standardized } \\
\text { Coefficients }\end{array} \\
\text { Beta }\end{array}$} & \multirow[t]{2}{*}{$\mathrm{t}$} & \multirow[t]{2}{*}{ Sig. } \\
\hline & $\mathrm{B}$ & Std. Error & & & \\
\hline (Constant) & 11.904 & 11.007 & & 1.081 & .286 \\
\hline $\begin{array}{l}\text { Sistem Informasi } \\
\text { Akuntansi }\end{array}$ & .109 & .258 & .059 & 2.94 & .675 \\
\hline Pengendalian Internal & .673 & .171 & .544 & 2,92 & .000 \\
\hline
\end{tabular}

Sumber: Hasil Penelitian (data diolah) 2021.

Hasil tabel di atas menggambarkan persamaan analisis regresi berganda sebagaimana yang telah penulis uraikan sebelumnya, yaitu :

$\mathrm{Y}=1,081+2,94 \mathrm{X}_{1}+2,92 \mathrm{X}_{2}$

Dari persamaan coefficients di atas dapat penulis interprestasikan sebagai berikut :

1) $\mathrm{a}=1094$ atau konstanta regresi, yang berarti jika ada nilai independent variable $\mathrm{X} 1$ (Sistem Informasi Akuntansi ) dan independent variable X2 (Pengendalian Internal ). Dalam hal ini X1, X2 sama dengan 0 (nol) maka Pengendalian Piutang bertambah 2.94 .

2) $\mathrm{b} 1=2,94$, untuk independent variable $X 1$ (sistem informasi akuntansi ) yang bertanda positif berarti memiliki hubungan yang searah yang artinya setiap penambahan atau kenaikan sebesar 1 satuan akan menambah jumlah pengendalian piutang sebesar 2,94. sebaliknya bila terjadi penurunan pada sistem informasi akuntansi maka jumlah Pengendalian Piutang akan turun sebesar 2.94 .
3) b2 $=2.92$, untuk independent variable $X 2$ (pengendalian internal ) yang bertanda positif berarti memiliki hubungan yang searah yang artinya bahwa setiap kenaikan atau penambahan sebesar 1 satuan akan menambah jumlah pengendalian piutang sebesar 2.92, sebaliknya bila terjadi penurunan Pengendalian Internal sebesar 1 satuan maka akan terjadi penurunan Pengendalian Piutang sebesar 2.92 pula.

Pada analisis dan evaluasi penulis ingin melihat pengaruh atau peran antara tiga independent. Independent variable X1 (Sistem Informasi Akuntansi) maupun independent variable X2 (Pengendalian Internal ) dan Independent variabel terhadap Pengendalian Piutang (Y), maka seharusnya peran atau pengaruh yang ditimbulkan setuju itu oleh Sistem Informasi Akuntansi dan Pengendalian Internal dan masa kerja yerhadap Pengendalian Piutang harus dipertimbangkan.

\subsection{Uji F.}

Adapun tabel Anova yang penulis maksud adalah seperti terlihat pada tabel dibawah ini. 
Tabel 10. Uji F

ANOVA(b)

\begin{tabular}{|l|l|r|r|r|r|l|}
\hline $\begin{array}{l}\text { Mode } \\
1\end{array}$ & & \multicolumn{1}{c|}{$\begin{array}{c}\text { Sum of } \\
\text { Squares }\end{array}$} & \multicolumn{1}{c|}{ df } & \multicolumn{1}{c|}{$\begin{array}{c}\text { Sean } \\
\text { Square }\end{array}$} & F & Sig. \\
\hline 1 & Regression & 157.871 & 2 & 78.935 & 8.285 & $.001(\mathrm{a})$ \\
\hline & Residual & 352.504 & 37 & 9.527 & & \\
\hline & Total & 510.375 & 39 & & & \\
\hline
\end{tabular}

Sumber : Hasil Penelitian (data diolah) 2021.

Diketahui $\mathrm{F}$ hitung sebesar 8,285 dengan tingkat signifikan 0,001 . jadi $\mathrm{F}$ hitung lebih besar dari $\mathrm{F}$ tabel $(8,285>4,08)$ atau sig $\mathrm{F}<5 \%$ $(0,001<0,05)$. Artinya bahwa secara bersamasama variabel Sistem Informasi akuntansi, pengendalian internal berpengaruh signifikan secara simultan terhadap pengendalian piutang (Y). dengan ini dapat disimpulkan bahwa

\subsection{Uji Determinan}

Pengaruh sistem informasi akuntansi dan Pengendalian Internal terhadap Pengendalian Piutang dapat dilihat pada tabel model summary yang penulis peroleh dari pengolahan data dengan program SPSS sebagai berikut : hipotesis dari penelitian ini dapat terbukti.

Tabel 11

Model Summary

\begin{tabular}{|l|r|r|r|r|}
\hline Model & $\mathrm{R}$ & R Square & \multicolumn{1}{c|}{$\begin{array}{c}\text { Adjusted R } \\
\text { Square }\end{array}$} & $\begin{array}{c}\text { Std. Error of the } \\
\text { Estimate }\end{array}$ \\
\hline 1 & $.556(\mathrm{a})$ & .309 & .272 & 3.08661 \\
\hline
\end{tabular}

Sumber : Hasil Penelitian (data diolah) 2021.

Sesuai tabel di atas, diperoleh $\mathrm{R}$ square untuk Y (Pengendalian Piutang) adalah 0.556. hal ini berarti $55,60 \%$ variasi Pengendalian Piutang (Y) dipengaruhi oleh variabel X1 (Sistem Informasi Akuntansi ) dan variabel X2 (Pengendalian Internal ) atau pengaruh tingkat Sistem Informasi Akuntansi (X1) dan Pengendalian Internal (X2) secara bersama- sama atau serentak terhadap variabel $\mathrm{Y}$ (Pengendalian Piutang ) sebesar $44,40 \%$ dan sisanya sebesar $69,10 \%$ ditentukan oleh variabel lain.

Selanjutnya dari pengolahan data dengan program SPSS tersebut penulis juga memperoleh correlations sebagai berikut :

Tabel 12

Correlations

\begin{tabular}{|c|c|c|c|c|}
\hline & & $\begin{array}{l}\text { Pengendalian } \\
\text { Piutang }\end{array}$ & $\begin{array}{l}\text { Sistem Informasi } \\
\text { Akuntansi }\end{array}$ & $\begin{array}{l}\text { Pengendalian } \\
\text { Internal }\end{array}$ \\
\hline \multirow[t]{3}{*}{$\begin{array}{l}\text { Pearson } \\
\text { Correlation }\end{array}$} & $\begin{array}{l}\text { Pengendalian } \\
\text { Piutang (y) }\end{array}$ & 1.000 & .143 & .553 \\
\hline & $\begin{array}{l}\text { Sistem Informasi } \\
\text { Akuntansi (X1) }\end{array}$ & .143 & 1.000 & .155 \\
\hline & $\begin{array}{l}\text { Pengendalian } \\
\text { Internal (X2) }\end{array}$ & .553 & .155 & 1.000 \\
\hline \multirow[t]{3}{*}{$\begin{array}{l}\text { Sig. (1- } \\
\text { tailed) }\end{array}$} & $\begin{array}{l}\text { Pengendalian } \\
\text { Piutang (y) }\end{array}$ & & .190 & .000 \\
\hline & $\begin{array}{l}\text { Sistem Informasi } \\
\text { Akuntansi (X1) }\end{array}$ & .190 & . & .170 \\
\hline & $\begin{array}{l}\text { Pengendalian } \\
\text { Internal (X2) }\end{array}$ & .000 & .170 & \\
\hline \multirow[t]{2}{*}{$\mathrm{N}$} & $\begin{array}{l}\text { Pengendalian } \\
\text { Piutang (y) }\end{array}$ & 40 & 40 & 40 \\
\hline & $\begin{array}{l}\text { Sistem Informasi } \\
\text { Akuntansi (X1) }\end{array}$ & 40 & 40 & 40 \\
\hline
\end{tabular}




\begin{tabular}{|l|l|l|r|r|}
\hline & \multicolumn{1}{|c|}{$\begin{array}{c}\text { Pengendalian } \\
\text { Piutang }\end{array}$} & $\begin{array}{c}\text { Sistem Informasi } \\
\text { Akuntansi }\end{array}$ & $\begin{array}{c}\text { Pengendalian } \\
\text { Internal }\end{array}$ \\
\hline & $\begin{array}{l}\text { Pengendalian } \\
\text { Internal (X2) }\end{array}$ & 40 & 40 & 40 \\
\hline
\end{tabular}

Sumber : Hasil Penelitian (data diolah) 2021.

Sesuai tabel di atas jelas terlihat hubungan korelasi ( $\mathrm{r}$ ) antara dependent variable (y) dalam hal ini Pengendalian Piutang dengan independent variable (X1) yaitu Sistem Informasi Akuntansi sebesar 0,143. Sedangkan hubungan korelasi antara independent variabel (X2) yaitu Pengendalian Internal 0,553, maka independent variable Pengendalian Internal (X2) lebih berpengaruh terhadap Pengendalian Piutang di PT. Barokah Fajar Sejahtera dibandingkan dengan Sistem Informasi Akuntansi (X1) yang memiliki pengaruh lebih kecil terhadap Pengendalian Piutang PT. Barokah Fajar Sejahtera .

Sebagaimana penelitian dan pengujian terlihat bahwa variabel bebas $(\mathrm{X} 1, \mathrm{X} 2$ memilki koefisien $b$ yang positif, berarti seluruh variabel bebas (Sistem Informasi Akuntansi , Pengendalian Internal ) mempunyai pengaruh yang searah terhadap variabel Y (Pengendalian Piutang ).

\section{Pembahasan.}

Adapun pembahasan yang telah diuraikan, maka dapat diketahui bahwa terdapat pengaruh positif antara Sistem Informasi Akuntansi $\left(\mathrm{X}_{1}\right)$ terhadap variabel Pengendalian Piutang (Y) dengan koefisien regresi 1.94. selanjutnya terdapat pengaruh positif variabel Pengendalian Internal (X2) terhadap variabel Pengendalian Piutang (Y) yang ditunjukkan oleh koefisien regresi 2.92 .

Uji simultan terdapat pengaruh antara Sistem Informasi Akuntansi $\left(\mathrm{X}_{1}\right)$ dan Pengendalian Internal $\left(\mathrm{X}_{2}\right)$ secara bersamasama terhadap produktivitas kinerja karyawan di PT. Barokah Fajar Sejahtera sebagaimana uji $F$ yaitu 8,285 atau $F$ tabel $(8,285>4,08)$.

Kemudian diperoleh $\mathrm{R}$ square untuk $\mathrm{Y}$ (Pengendalian Piutang ) adalah 0,309. hal ini berarti 55,60\% variasi Pengendalian Piutang (Y) dipengaruhi oleh variabel X1 (Sistem Informasi Akuntansi ) dan variabel X2 (Pengendalian Internal) atau pengaruh tingkat Sistem Informasi Akuntansi (X1) dan Pengendalian Internal (X2) secara bersamasama atau serentak terhadap variabel $Y$ (Pengendalian Piutang ) sebesar 55,60\% dan sisanya sebesar $44,40 \%$ ditentukan oleh variabel lain.

Penilaian tersebut diatas menerima hasil hipotesis penelitian ini, yakni penilaian Sistem Informasi Akuntansi dan Pengendalian Internal berpengaruh positif dan signifikan terhadap Pengendalian Piutang PT. Barokah Fajar Sejahtera sebesar 55,60\% yang merupakan gambaran umum dari seluruh populasi. Dalam penelitian ini jumlah sample 40 orang. Berarti gambaran hasil penelitian ini juga merupakan gambaran dari seluruh anggota populasi yang berjumlah 40 orang.

\section{Kesimpulan}

Berdasarkan tabel sebagaimana yang diuraikan di atas maka dapat ditarik kesimpulan sebagai berikut :

1) Sistem Informasi Akuntansi berpengaruh positif dan signifikan terhadap pengendalian piutang sebagaimana hasil penelitian berdasarkan uji t bahwa t-hitung lebih besar dari t-tabel yaitu 2,94 $>2.02$.

2) Pengendalian Internal berpengaruh positif dan signifikan terhadap pengendalian piutang sebagaimana hasil penelitian berdasarkan uji t bahwa t-hitung lebih besar dari t-tabel yaitu 2,92> 2.02 .

3) Secara simultan atau bersama Sistem Informasi Akuntansi $\left(\mathrm{X}_{1}\right)$ dan Pengendalian Internal $\left(\mathrm{X}_{2}\right)$ berpengaruh terhadap Pengendalian Piutang (Y) sebagaimana perhitungan uji simultan yaitu F-hitung lebih besar dari f-tabel atau 8,285>4,08. Adapun besaran pengaruh dari variable $\mathrm{X}_{1}, \mathrm{X}_{2}$ terhadap[ variable $\mathrm{Y}$ berdasarkan uji determinan adalah $55,60 \%$

\section{DAFTAR PUSTAKA}

Adisaputo, Gunawan dan Asri, Marwan,2014, Anggaran Perusahaan. (PBFE Bell and Brown, 2016, Lana Akuntansi dan Arus Kas Investor, Terjemahan Aria Farahmita dan Amanugrahani, Salemba Empat, Jakarta.

Carl S. Warren. 2016. Pengantar Akuntansi. Jakarta: Salemba Empat.

Dyckman, Dukes, Davis.2013, Akuntansi Intermediate, Edisi Keempat,Jilid I, Terjemahan Munir Ali, Jakarta 
Galloway Bottleselle, 2017, Akuntansi Keuangan Perusahaan, Terjemahan Munir Ali, Jakarta

Haryono Jusup, 2018, Dasar-Dasar Akuntansi, Jidil 1 Edisi 7, Jakarta : Tinda Pustaka.

Hani Handoko. 2014. Manajemen Personalia dan Sumber Daya Manusia. BPFE:Yogyakarta.

Hanafi, 2015, Budgeting, Penganggaran, Perencanaan Lengkap, Edisi Kelima, Jakarta : Raja Grafindo Persada

Ikatan Akuntan Indonesia. 2018. Standar Akuntansi Keuangan. Cetakan Pertama.Salemba Empat: Jakarta.

Ikatan Akuntan Indonesia.2017, Standar Akuntansi Keuangan, Salemba Empat, Jakarta.

Kasmir. 2017. Analisis Laporan Keuangan. Cetakan Ke-5.PT. Raja GrafindoPersada; Jakarta.

Kieso Weygandt Warfield. 2015. Akuntansi Keuangan Menengah (IntermediateAccounting). Salemba Empat: Jakarta.

Mamduh M. Hanafi. 2015. Analisis Laporan Keuangan. UPP STIM YKPN:Yogyakarta.
Martono. 2015. Manajemen Keuangan. Ekonisia: Jakarta.

Maria Dewi dan Puspita Rama (2012) Analisis Tingkat Penjualan Dan Persediaan Barang Dagang Terhadap Laba Perusahaan Pada PT Balam Jaya Sentosa Kota Batam

Mulyadi.Kanaka Puradireja.2012, Auditing, Buku Dua, Edisi Keenam, Salemba Empat, Jakarta.

Rangkuti, Freddy.2014, Manajemen Persediaan: Aplikasi Di Bidang Bisnis, Edisi Ketiga, Radja Grafindo Persada, Jakarta.

Sugiyono. 2016. Metodologi Penelitian Manajemen. Bandung: Alfabeta.

Sigit Hermawan. 2013. Akuntansi Perusahaan Manufaktur. SIUP: Jakarta.

Soemarso. 2014. Akuntansi Suatu Pengantar. Salemba Empat: Jakarta.

Wilson, 2013, Manajemen Akuntansi,,Jakarta : Bumi Aksara.

Yunarni dan Sugiyarso (2021.) Tunai dan Penjulan Kredit Terhadap Laba Pada Industri Bengkel Las Diana di Palopo. 